\title{
Decreased susceptibility to renovascular hypertension in mice lacking the prostaglandin $\mathrm{I}_{2}$ receptor IP
}

\author{
Takayuki Fujino, ${ }^{1}$ Naoki Nakagawa, ${ }^{1}$ Koh-ichi Yuhki, ${ }^{1}$ Akiyoshi Hara, ${ }^{1}$ Takehiro Yamada, ${ }^{1}$ \\ Koji Takayama, ${ }^{1}$ Shuhko Kuriyama, ${ }^{1}$ Yayoi Hosoki, ${ }^{1}$ Osamu Takahata, ${ }^{1}$ Takanobu Taniguchi, ${ }^{2}$ \\ Jun Fukuzawa, ${ }^{3}$ Naoyuki Hasebe, ${ }^{3}$ Kenjiro Kikuchi, ${ }^{3}$ Shuh Narumiya, ${ }^{4}$ and Fumitaka Ushikubi \\ 1Department of Pharmacology, ${ }^{2}$ Department of Biochemistry, and ${ }^{3}$ First Department of Internal Medicine, Asahikawa Medical College, Asahikawa, Japan. \\ ${ }^{4}$ Department of Pharmacology, Faculty of Medicine, Kyoto University, Kyoto, Japan.
}

\begin{abstract}
Persistent reduction of renal perfusion pressure induces renovascular hypertension by activating the reninangiotensin-aldosterone system; however, the sensing mechanism remains elusive. Here we investigated the role of $\mathrm{PGI}_{2}$ in renovascular hypertension in vivo, employing mice lacking the $\mathrm{PGI}_{2}$ receptor $\left(\mathrm{IP}^{-/-}\right.$mice). In $\mathrm{WT}^{-}$ mice with a two-kidney, one-clip model of renovascular hypertension, the BP was significantly elevated. The increase in BP in $I P^{-/-}$mice, however, was significantly lower than that in WT mice. Similarly, the increases in plasma renin activity, renal renin mRNA, and plasma aldosterone in response to renal artery stenosis were all significantly lower in $\mathrm{IP}^{-/-}$mice than in WT mice. All these parameters were measured in mice lacking the four $\mathrm{PGE}_{2}$ receptor subtypes individually, and we found that these mice had similar responses to WT mice. $\mathrm{PGI}_{2}$ is produced by COX-2 and a selective inhibitor of this enzyme, SC-58125, also significantly reduced the increases in plasma renin activity and renin mRNA expression in WT mice with renal artery stenosis, but these effects were absent in $I P^{-/-}$mice. When the renin-angiotensin-aldosterone system was activated by salt depletion, SC-58125 blunted the response in WT mice but not in $I P^{-/-}$mice. These results indicate that $\mathrm{PGI}_{2}$ derived from $\mathrm{COX}-2$ plays a critical role in regulating the release of renin and consequently renovascular hypertension in vivo.
\end{abstract}

\section{Introduction}

In renovascular hypertension, the reduction of renal blood flow due to renal artery stenosis originating from obstructive vascular diseases, such as atherosclerosis or fibromuscular dysplasia, induces excessive activation of the renin-angiotensin-aldosterone (RAA) system and leads to hypertension (1). In patients and animal models of renovascular hypertension, expression of COX-2, a rate-limiting enzyme for prostanoid synthesis, has been reported to be increased in the kidneys $(2,3)$. In addition, production of $\mathrm{PGE}_{2}$ and $\mathrm{I}_{2}$ in the kidney has been reported to be increased during renovascular hypertension $(4,5)$, suggesting that the prostanoids play an important role in the pathogenesis of renovascular hypertension. The roles of the prostanoids in renovascular hypertension, however, have not yet been fully defined.

The RAA system plays an important role in the maintenance of vascular tone, circulating blood volume, and electrolyte balance in the body. Renin is a rate-limiting enzyme involved in the activation of the RAA system and is secreted from the granular cells of juxtaglomerular apparatus (JGA) in the kidney. It converts plasma angiotensinogen to Ang I, which is successively changed to Ang II, a powerful vasoconstrictor, by angiotensin-converting enzyme present on the epithelial cells of pulmonary vasculatures. Ang II acts on the adrenal cortex and stimulates the secretion of aldosterone, which facilitates sodium reabsorption in the kidney and expands the

Nonstandard abbreviations used: EIA, enzyme immunoassay; JG, juxtaglomerular; JGA, juxtaglomerular apparatus; 2K1C, two-kidney, one-clip; PAC, plasma aldosterone concentration; PRA, plasma renin activity; RAA, renin-angiotensin-aldosterone; sBP, systolic BP.

Conflict of interest: The authors have declared that no conflict of interest exists.

Citation for this article: J. Clin. Invest. 114:805-812 (2004)

doi:10.1172/JCI200421382. circulating blood volume. Thus, Ang II and aldosterone are thought to be important players in the control of BP; therefore, renin secretion is precisely regulated through two major sensing mechanisms, along with regulation by the sympathetic nervous system. One mechanism is the baroreceptor mechanism, which senses the reduction in renal perfusion pressure and increases renin secretion (6). This mechanism is thought to reside in the renal vasculature itself and to be independent of renal tubular elements, although its exact location remains unknown. The other is the macula densa mechanism, which senses the decrease in the concentration of chloride ions in glomerular filtrate at the macula densa cells and increases renin secretion (6). The macula densa cell, a differentiated tubular epithelial cell, is one of those composing the JGA. These two sensing mechanisms transmit their information to the granular cells via the respective mediators (6). The role of the prostanoids as such mediators, however, especially in vivo, remains to be determined.

It is well established that cAMP works as a second messenger of renin secretagogues, such as norepinephrine, in the granular cells of JGA and that the increase in intracellular cAMP concentration induces renin secretion (7). $\mathrm{PGE}_{2}$ exerts its action through four subtype receptors, the $\mathrm{EP}_{1}, \mathrm{EP}_{2}, \mathrm{EP}_{3}$, and $\mathrm{EP}_{4}$, and $\mathrm{PGI}_{2}$ acts on its receptor IP. Stimulation of the $\mathrm{EP}_{2}, \mathrm{EP}_{4}$, and IP increases intracellular cAMP concentration, indicating that these receptors could mediate the stimulatory signal for renin secretion. In contrast, stimulation of the $\mathrm{EP}_{1}$ and $\mathrm{EP}_{3}$ leads to the increase in intracellular $\mathrm{Ca}^{2+}$ concentration and the decrease in intracellular cAMP concentration, respectively $(8,9)$. In addition, $\mathrm{PGE}_{2}$ and $\mathrm{PGI}_{2}$ have been reported to stimulate renin secretion in cultured juxtaglomerular (JG) cells (10). These results suggest that $\mathrm{PGE}_{2}$ and $\mathrm{PGI}_{2}$ work as mediators of renin secretion acting directly on the granular cells, while their in vivo actions in the regulation of renin secretion are not known. 
A

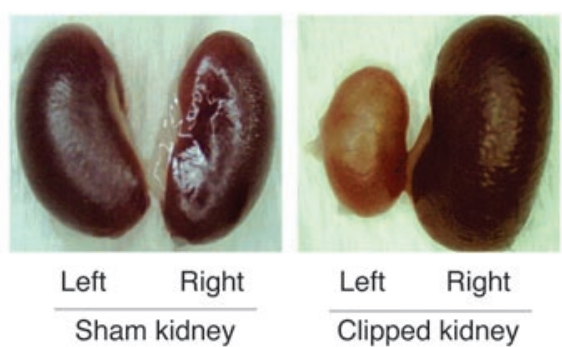

B
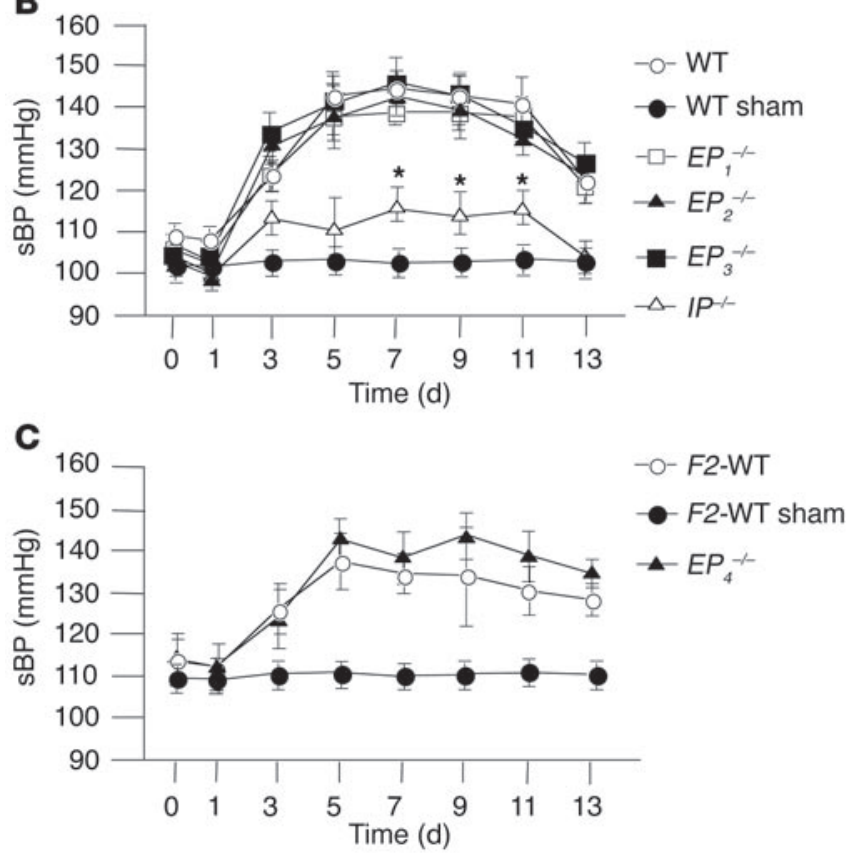

In the present study, we attempted to clarify the roles of $\mathrm{PGE}_{2}$ and $\mathrm{PGI}_{2}$ in the pathogenesis of renovascular hypertension employing a two-kidney, one-clip (2K1C) hypertension model using mice lacking the $\mathrm{EP}_{1}\left(E_{P_{1}^{-/-}}\right.$mice $), \mathrm{EP}_{2}\left(\mathrm{EP}_{2}^{-/-}\right.$mice $), \mathrm{EP}_{3}\left(\mathrm{EP}_{3}{ }^{-/-}\right.$mice $)$, $\mathrm{EP}_{4}\left(\mathrm{EP}_{4}^{-/-}\right.$mice $)$, or IP $\left(I P^{-/-}\right.$mice $)$.

\section{Results}

Renovascular bypertension in 2K1C model. At day 14 of 2K1C, the left kidney became atrophic and the right kidney showed compensatory hypertrophy (Figure 1A). The degree of atrophic

\section{Figure 2}

Activation of the RAA system in $\mathrm{WT}$ and $I P^{-/-}$mice in $2 \mathrm{~K} 1 \mathrm{C}$ model. (A and $\mathbf{B})$ Increases in PRA (A) and renin mRNA expression in the kidney (B) at day 7 of $2 \mathrm{~K} 1 \mathrm{C}$. Each column represents mean \pm SEM of $5-15$ mice per group. In $\mathbf{B}$ values were expressed as a ratio of renin/ $\beta$-actin mRNA of $2 \mathrm{~K} 1 \mathrm{C}$ mice to that of sham-operated mice. ${ }^{*} P<0.05$ versus WT mice. (C) Immunohistochemical analysis of renin expression in the WT kidney in 2K1C model. The immunoreactivities of renin in the kidney from the sham-operated WT mouse were detected only in the cells of JGA (left). The immunoreactivities of renin in the kidney at day 7 of $2 \mathrm{~K} 1 \mathrm{C}$ were detected in the afferent arterioles adjacent to JGA in addition to in JG cells (right). Arrows indicate the renin immunoreactivities. Original magnification, $\times 400$. (D) Increase in PAC at day 7 of $2 \mathrm{~K} 1 \mathrm{C}$. Each column represents mean \pm SEM of $5-15$ mice per group. ${ }^{\star} P<0.05$ versus WT mice. Pre-ope, preoperation.

\section{Figure 1}

Morphological changes of the kidneys and renovascular hypertension in 2K1C model. (A) Representative photographs of the kidneys from sham-operated WT mice (left) and from mice subjected to $2 \mathrm{~K} 1 \mathrm{C}$ (right). At day 14 of $2 \mathrm{~K} 1 \mathrm{C}$, the left kidney became atrophic and the right kidney showed compensatory hypertrophy. (B and C) Time course of sBP in WT, sham-operated WT, $E P_{1}^{-/-}, E P_{2}{ }^{-1-}, E P_{3}^{-/-}$, and $I P^{-/-}$mice (B), and in F2-WT, sham-operated F2-WT, and $E P_{4}^{-/-}$mice (C) in $2 \mathrm{~K} 1 \mathrm{C}$ model. Each point represents mean \pm SEM of 8-10 mice per group. ${ }^{\star} P<0.05$ versus WT mice.

change estimated by weights of the left kidneys was similar among WT, $E P_{1}^{-/-}, \mathrm{EP}_{2}^{-/-}, \mathrm{EP}_{3}^{-/-}$, and $\mathrm{IP}^{-/-}$mice and between $\mathrm{F} 2$-WT and $\mathrm{EP}_{4}{ }^{-/-}$mice (data not shown), suggesting that the clipping of the renal artery induced a similar degree of ischemic stress to the left kidney in each mouse group.

In WT and F2-WT mice, systolic BP (sBP) rose gradually and reached a plateau at day 5 of $2 \mathrm{~K} 1 \mathrm{C}$, while there was no such increase in sBP in the sham-operated groups (Figure 1, B and C) measured by the tail-cuff method. In $I P^{-/-}$mice, however, the increase in sBP was significantly lower than that observed in WT mice (Figure 1B), suggesting an important pathophysiological role of $\mathrm{PGI}_{2}$ in renovascular hypertension. In contrast, there were no significant differences in the degree and time-course of hypertension in $\mathrm{EP}_{1}^{-/-}$, $\mathrm{EP}_{2}^{-{ }^{--}}, \mathrm{EP}_{3}^{-/-}$, and $\mathrm{EP}_{4}^{-/-}$mice compared with those in their respective WT mice (Figure 1, B and C), suggesting that there is a minor role, if any, for $\mathrm{PGE}_{2}$ in the present model of renovascular hypertension. When BP was measured directly through the cannula inserted into the carotid artery at day 7 of $2 \mathrm{~K} 1 \mathrm{C}$, the increase in sBP was significantly lower in $I P^{-/-}$mice compared with that in WT mice; these were $144 \pm 12,118 \pm 6$, and $104 \pm 5 \mathrm{mmHg}$ in WT, $I P^{-/-}$, and sham-operated WT mice, respectively. This result confirmed the decreased susceptibility of $I P^{-/-}$mice to renovascular hypertension as was observed by the tail-cuff method. The sBP in WT and F2-WT mice decreased gradually and returned to a preoperation
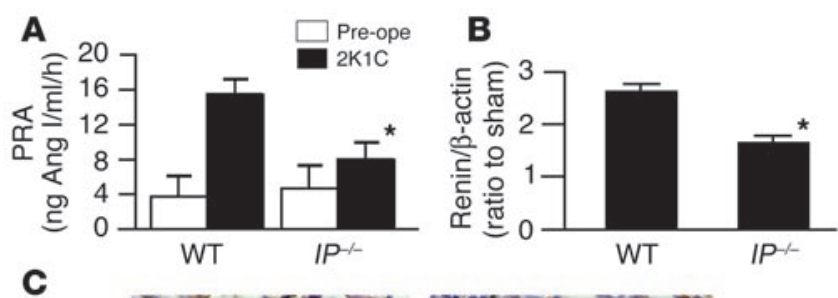

C
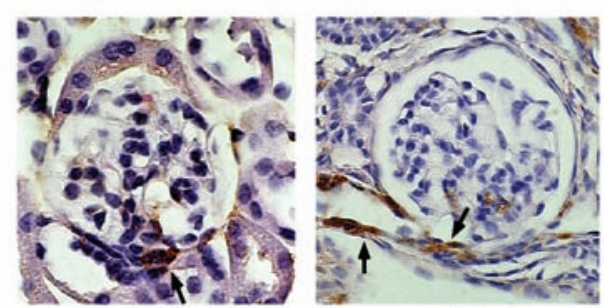

D
$2 \mathrm{~K} 1 \mathrm{C}$

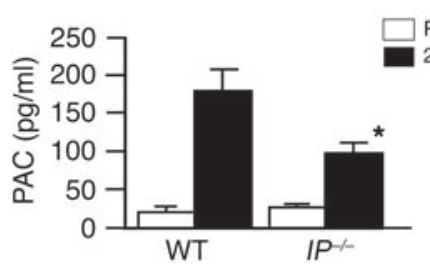




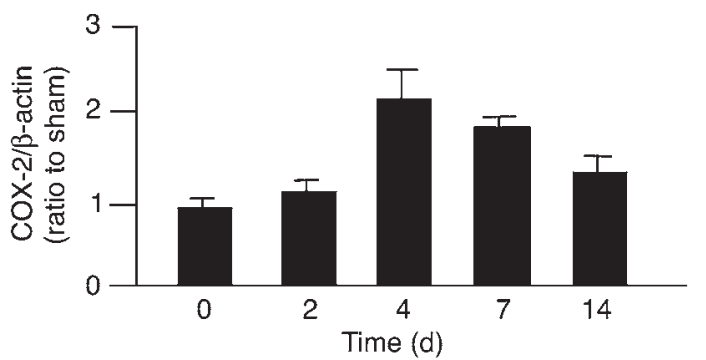

Figure 3

Expression of COX-2 mRNA in the WT kidney in $2 \mathrm{~K} 1 \mathrm{C}$ model. The expression of COX-2 mRNA increased significantly after the operation and reached a peak level at day 4 of $2 \mathrm{~K} 1 \mathrm{C}$. Each column represents mean \pm SEM of 5-12 mice per group. Values were expressed as a ratio of COX- $2 / \beta$-actin mRNA of $2 \mathrm{~K} 1 \mathrm{C}$ mice to that of sham-operated mice.

level within 3 weeks after the operation, as the left kidney fell into severe atrophy. Although we performed the present study using female mice, the degree and time course of hypertension in male WT and $I P^{-1-}$ mice subjected to $2 \mathrm{~K} 1 \mathrm{C}$ were similar to those in female mice (data not shown), indicating that there was no gender difference in the present phenotype.

The basal levels of heart rate were not significantly different among WT, $E P_{1^{--}},{E P_{2}^{-/-}}^{-1} \mathrm{EP}_{3^{--}}$, and $\mathrm{IP}^{-/-}$, or between $\mathrm{F} 2$-WT and $\mathrm{EP}_{4}{ }^{-1-}$ mice, and there were no significant changes in heart rate during the experiments in all groups of mice (data not shown). Plasma creatinine levels at day 14 of $2 \mathrm{~K} 1 \mathrm{C}$ were not significantly different among the mice groups (data not shown).

Activation of the RAA system in $2 \mathrm{~K} 1 \mathrm{C}$ model. To explore the mechanism whereby $\mathrm{PGI}_{2}$ induces hypertension in $2 \mathrm{~K} 1 \mathrm{C}$ model, we examined the role of $\mathrm{PGI}_{2}$ in renin secretion by examining plasma renin activity (PRA). In WT mice, PRA increased significantly at day 7 of $2 \mathrm{~K} 1 \mathrm{C}$, while there was no such increase in sham-operated WT mice (Figure 2A). In $I P^{-1-}$ mice, however, the increase in PRA was significantly lower than that in WT mice, suggesting a stimulatory effect of endogenous $\mathrm{PGI}_{2}$ on renin secretion. In contrast, there were no significant differences in the degree of increases in PRA between WT and $\mathrm{EP}_{2}^{-/-}$or $\mathrm{F} 2$-WT and $\mathrm{EP}_{4}^{-{ }^{-1}}$ mice (data not shown). In shamoperated WT and $I P^{-/-}$mice, there were no significant increases in PRA compared with preoperation values; these were $4.3 \pm 1.2$ and $5.0 \pm 1.6 \mathrm{ng} \mathrm{Ang} \mathrm{I/ml/h}$, respectively.

To determine if $\mathrm{PGI}_{2}$ has a stimulatory effect on renin production as well as secretion, we examined the expression of renin mRNA in the kidney. In WT mice, renal renin mRNA expression increased significantly at day 7 of $2 \mathrm{~K} 1 \mathrm{C}$ (Figure 2B). In $I P^{-/-}$mice, however, the increase in the expression level was significantly lower than that in WT mice, suggesting that there is a stimulatory role of endogenous $\mathrm{PGI}_{2}$ in renin production. In contrast, there were no significant differences in the expression levels of renin mRNA among WT, $E P_{1}^{-/-}$, $\mathrm{EP}_{2}^{-/-}, \mathrm{EP}_{3}^{-/-}$kidneys or between $\mathrm{F} 2$-WT and $\mathrm{EP}_{4}^{-{ }^{-/}}$ kidneys (data not shown). The immunoreactivities of renin were detected only in JG cells in WT kidney at day 7 of sham operation (Figure 2C). In the clipped WT kidney, however, the immunoreactivities were found in the vascular cells of afferent arterioles near the glomerulus in addition to JG cells, indicating that transitional cells began to produce renin after $2 \mathrm{~K} 1 \mathrm{C}$.
In accordance with the increase in PRA, plasma aldosterone concentration (PAC) increased significantly in WT mice at day 7 of $2 \mathrm{~K} 1 \mathrm{C}$ (Figure 2D). In $I P^{-/-}$mice, however, the increase in PAC was significantly lower than that in WT mice, suggesting the activation of the RAA system by endogenous $\mathrm{PGI}_{2}$. In shamoperated WT and $I P^{-1-}$ mice, there were no significant increases in PAC compared with preoperation values; these were $19 \pm 7$ and $23 \pm 4 \mathrm{pg} / \mathrm{ml}$, respectively.

Expressions of COX $m R N A$ in the kidney and production of $P \mathrm{II}_{2}$ in $2 \mathrm{~K} 1 \mathrm{C}$ model. We further examined the expression of COX, the key enzymes for prostanoid synthesis. In WT kidney, the expression level of mRNA for COX-2, an inducible isoform of COX, increased significantly after the operation of $2 \mathrm{~K} 1 \mathrm{C}$ (Figure 3), indicating that the expression level of COX-2 mRNA increased, along with the increased expression of renin mRNA and the elevation of BP. There was no significant difference in the expression levels of COX-2 mRNA between WT and $I P^{-/-}$kidneys (data not shown), suggesting that a similar degree of prostanoid synthesis took place in $\mathrm{WT}$ and $I P^{-/-}$mice after $2 \mathrm{~K} 1 \mathrm{C}$. In contrast, the expression levels of COX-1 mRNA in the kidney did not change significantly after the operation in either WT or $I P^{-/-}$mice (data not shown).

There were no significant differences in basal concentrations of 6-keto-PGF $\mathrm{F}_{1} \alpha$, a stable metabolite of $\mathrm{PGI}_{2}$, in either urine or plasma between WT and $I P^{-/-}$mice (Table 1 ). In both WT and $I P^{-/-}$mice, concentrations of 6-keto-PGF $\alpha$ in urine and plasma increased significantly at day 7 of $2 \mathrm{~K} 1 \mathrm{C}$ compared with the basal values. There were no significant differences in these increases between WT and $\mathrm{IP}^{-/-}$mice, indicating that the COX-PGI 2 system was stimulated to a similar extent in WT and $I P^{-/-}$mice subjected to $2 \mathrm{~K} 1 \mathrm{C}$.

Effects of SC-58125 in the $2 \mathrm{~K} 1 \mathrm{C}$ model. To estimate the degree of participation of COX-2-derived $\mathrm{PGI}_{2}$ in the pathogenesis of renovascular hypertension, the effects of SC-58125 were examined. In WT mice, SC-58125 failed to affect BP in either WT or $I P^{-/-}$mice, but SC-58125 significantly reduced the increases in PRA and renin mRNA expression in WT mice to levels similar to those in vehicle-treated $I P^{-/-}$mice. In addition, SC-58125 had no effect on PRA or renin mRNA expression in $I P^{-/-}$mice, suggesting that $\mathrm{COX}-2$-derived $\mathrm{PGI}_{2}$ stimulated renin secretion and production. The concentrations of 6-keto-PGF $1 \alpha$ in urine and plasma decreased significantly in both WT and $I P^{-/-}$mice to a similar
Table 1

Effects of SC-58125 in 2K1C model

\begin{tabular}{lcccc} 
& \multicolumn{2}{c}{ WT } & \multicolumn{2}{c}{ IP-/ } \\
& Vehicle & SC-58125 & Vehicle & SC-58125 \\
SBP (mmHg) & $142 \pm 6$ & $129 \pm 9$ & $120 \pm 4$ & $127 \pm 3$ \\
PRA (ng Ang l/ml/h) & $15.5 \pm 1.8$ & $8.5 \pm 2.1^{\mathrm{A}}$ & $7.9 \pm 1.9$ & $7.3 \pm 2.9$ \\
Renin $\mathrm{mRNA}$ & $2.41 \pm 0.25$ & $1.95 \pm 0.17^{\mathrm{A}}$ & $1.93 \pm 0.25$ & $2.13 \pm 0.14$ \\
6-keto-PGF $1 \alpha$ & & & & \\
Urine $(\mathrm{pg} / \mathrm{mg}$ creatinine) & $5.32 \pm 0.35$ & $4.24 \pm 0.34^{\mathrm{A}}$ & $5.92 \pm 0.25$ & $4.11 \pm 0.24^{\mathrm{A}}$ \\
Plasma $(\mathrm{pg} / \mathrm{ml})$ & $167 \pm 12$ & $123 \pm 28^{\mathrm{A}}$ & $181 \pm 81$ & $112 \pm 18^{\mathrm{A}}$
\end{tabular}

Effects of SC-58125 on sBP, PRA, renin mRNA expression, and concentrations of 6-keto-PGF ${ }_{1} \alpha$ in urine and plasma were examined in WT and $I P^{-/-}$mice at day 7 of $2 \mathrm{~K} 1 \mathrm{C}$. Vehicle or SC-58125 (10 mg/kg/day) was injected at days 5 and 6 of $2 \mathrm{~K} 1 \mathrm{C}$. Basal concentrations of 6-keto-PGF ${ }_{1} \alpha$ in urine were $1.72 \pm 0.10$ and $2.08 \pm 0.10 \mathrm{pg} / \mathrm{mg}$ creatinine in WT and $I P^{-/-}$mice, respectively. These values in plasma were $110 \pm 4$ and $112 \pm 13 \mathrm{pg} / \mathrm{ml}$, respectively. Values for renin mRNA expression were expressed as a ratio of renin/ $\beta$-actin mRNA of $2 \mathrm{~K} 1 \mathrm{C}$ mice to that of sham-operated mice. Values represent mean \pm SEM of $6-10$ mice per group. ${ }^{A} P<0.05$ versus vehicle-treated group. 


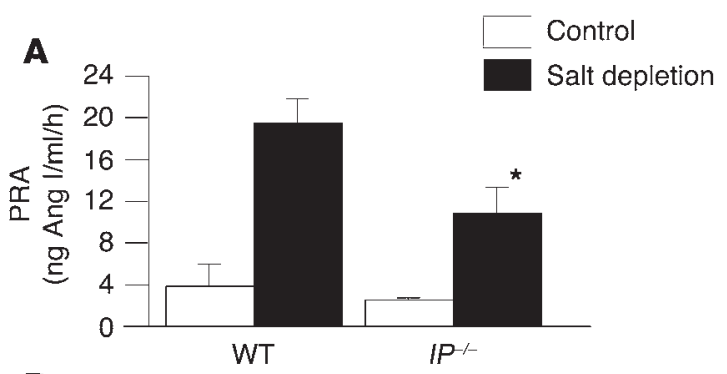

B

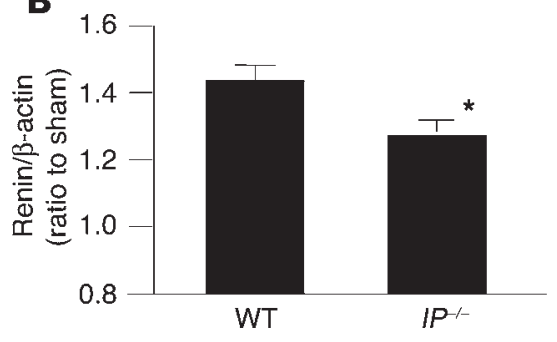

Figure 4

PRA and renin mRNA expression in the kidney in a salt-deficiency model. Mice were subjected to a low-salt diet $(0.12 \% \mathrm{NaCl})$ for 7 days and injected with furosemide (25 mg/kg, intraperitoneally) every day. PRA (A) and renin mRNA expression (B) increased significantly more than in control mice at day 7 of salt depletion. These increases were blunted significantly in $I P^{-/-}$mice compared with those in WT mice. Each column represents mean \pm SEM of 5-12 mice per group. Values in $\mathbf{B}$ were expressed as a ratio of renin/ $\beta$-actin mRNA of salt-depleted mice to that of control mice. ${ }^{*} P<0.05$ versus WT mice.

extent under SC-58125 treatment. SC-58125 had no effect on BP or PRA in sham-operated WT and $I P^{-/-}$mice (data not shown).

Activation of the RAA system under low-salt diet with furosemide. In WT mice subjected to low-salt diet with furosemide, PRA increased significantly compared with that in WT control mice (Figure 4A). In $I P^{-/-}$mice under salt deficiency, however, the increase in PRA was significantly lower than that in WT mice. In $\mathrm{EP}_{2}^{-{ }^{--}}$and $\mathrm{EP}_{4}^{-{ }^{-/}}$mice, the increases in PRA were similar to those in WT and F2-WT mice, respectively (data not shown). In addition, salt deficiency significantly increased the renin mRNA expression in the WT kidney compared with that in the control kidney. In $I P^{-/-}$kidney, however, the degree of the increase was significantly lower than that in WT kidney (Figure 4B). These results suggest that $\mathrm{PGI}_{2}$ participates as an important mediator in the macula densa mechanism of renin release and production, as well as in the baroreceptor mechanism observed in 2K1C model.

Expression levels of COX-2 mRNA increased significantly under salt deficiency in both WT and $I P^{-/-}$kidneys to a similar degree; these were $21 \% \pm 5 \%$ and $19 \% \pm 3 \%$ increase over respective control levels. Expression levels of COX-1 mRNA, however, were unchanged in both WT and $I P^{-/-}$kidneys (data not shown). Urinary contents of 6-keto-PGF $1 \alpha$ increased significantly upon salt depletion in both WT and $I P^{-/-}$mice compared with their respective control mice, but the plasma levels of 6-keto-PGF ${ }_{1} \alpha$ did not change significantly in either WT or $I P^{-/-}$mice (Table 2 ), suggesting that $\mathrm{PGI}_{2}$ production increased mainly in renal tubular system under saltdeficient conditions. SC-58125 significantly reduced
6-keto-PGF $\alpha$ contents in urine and plasma in both WT and $I P^{-/-}$ mice (Table 2). In addition, SC-58125 significantly reduced the increases in PRA and renin mRNA expression in WT mice subjected to salt depletion compared with those in vehicle-treated WT mice (Table 2). In $I P^{-1-}$ mice, however, SC-58125 had no significant effects on PRA or renin mRNA expression, supporting the theory that COX-2-derived $\mathrm{PGI}_{2}$ also participates in the regulation of renin release and production under salt-deficient conditions.

Effects of cicaprost and $P G E_{2}$ on renin $m R N A$ expression in the cultured cells rich in JG cells. Cicaprost, an IP agonist, stimulated renin mRNA expression in the cultured JG cells prepared from WT mice in a concentration-dependent manner with a median effective concentration $\left(\mathrm{EC}_{50}\right)$ value of $1.05 \times 10^{-8} \mathrm{M}$ (Figure 5). In the JG cells from $I P^{-1-}$ mice, however, the stimulatory effect of cicaprost on renin mRNA expression disappeared completely, indicating that the effect of cicaprost was mediated by the IP. In contrast, $\mathrm{PGE}_{2}$ did not stimulate the expression of renin mRNA at all (Figure 5), ruling out $\mathrm{PGE}_{2}$ as a direct stimulator of JG cells. In accordance with this result, all of the selective agonists for each EP subtypes failed to increase renin mRNA expression in the cultured JG cells prepared from WT mice (data not shown).

Effects of cicaprost on renin activity and cAMP contents in the cultured cells rich in JG cells. Cicaprost significantly increased renin activity in the cultured JG cells prepared from WT mice, but the effect disappeared in the cultured JG cells prepared from $I P^{-1-}$ mice (Figure $6 \mathrm{~A}$ ), showing a potent stimulatory effect of $\mathrm{PGI}_{2}$ through the IP on renin activity. In contrast, all of the selective EP agonists failed to increase renin activity in the cultured JG cells prepared from WT mice (data not shown).

Cicaprost significantly increased cAMP contents in the cultured cells prepared from WT mice, while the effect disappeared in the cultured cells prepared from $I P^{-/-}$mice (Figure 6B). This result suggests that the stimulatory effects of cicaprost by way of the IP on the renin mRNA expression and renin activity in the JG cells would be mediated by the increase in intracellular cAMP concentration.

\section{Discussion}

The prostanoids have long been suggested to be involved in the regulation of the RAA system. Their exact contribution to the pathophysiology of the activated RAA system in vivo and the types

\section{Table 2}

Effects of SC-58125 in salt-deficiency model

\begin{tabular}{lcccc} 
& \multicolumn{2}{c}{ WT } & \multicolumn{2}{c}{ IP-/ } \\
& Vehicle & SC-58125 & Vehicle & SC-58125 \\
PRA (ng Ang I/ml/h) & $19.6 \pm 2.2$ & $10.6 \pm 3.1^{\mathrm{A}}$ & $10.8 \pm 2.4$ & $8.6 \pm 3.2$ \\
Renin $\mathrm{mRNA}$ & $1.44 \pm 0.04$ & $1.22 \pm 0.06^{\mathrm{A}}$ & $1.31 \pm 0.07$ & $1.36 \pm 0.07$ \\
6-keto-PGF $1 \alpha$ & & & & \\
Urine $(\mathrm{pg} / \mathrm{mg}$ creatinine) & $2.86 \pm 0.14$ & $2.46 \pm 0.08^{\mathrm{A}}$ & $2.93 \pm 0.11$ & $2.41 \pm 0.08^{\mathrm{A}}$ \\
Plasma $(\mathrm{pg} / \mathrm{ml})$ & $115 \pm 15$ & $69 \pm 10^{\mathrm{A}}$ & $120 \pm 10$ & $66 \pm 10^{\mathrm{A}}$ \\
& & & & \\
\hline
\end{tabular}

Effects of SC-58125 on PRA, renin mRNA expression, and concentrations of 6-keto-PGF $1 \alpha$ in urine and plasma were examined in $W^{-}$and $I P^{-1-}$ mice at day 7 of salt depletion. Vehicle or SC-58125 (10 mg/kg/day) was injected at days 5 and 6 of salt depletion. Basal concentrations of $6-$ keto- $^{-} \mathrm{PGF}_{1} \alpha$ in urine were $1.72 \pm 0.10$ and $2.08 \pm 0.10 \mathrm{pg} / \mathrm{mg}$ creatinine in $W T$ and $I P^{-/}$mice, respectively. These values in plasma were $110 \pm 4$ and $112 \pm 13 \mathrm{pg} / \mathrm{ml}$, respectively. Values for renin mRNA expression were expressed as a ratio of renin/ $\beta$-actin mRNA of salt-depleted mice to that of control mice. Values represent mean \pm SEM of $4-10$ mice per group. ${ }^{A} P<0.05$ versus vehicle-treated group. 
A

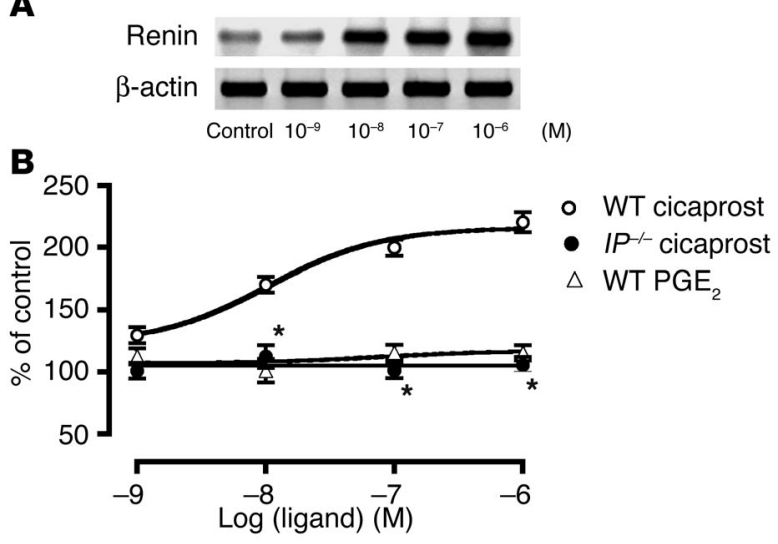

\section{Figure 5}

Effects of cicaprost, an IP agonist, and $\mathrm{PGE}_{2}$ on renin mRNA expression in cultured cells rich in JG cells. (A) A representative photograph showing stimulatory effects of cicaprost on renin mRNA expression in cultured cells prepared from WT mice. (B) Cicaprost significantly increased the expression level of renin mRNA in a concentrationdependent manner in the cells prepared from WT mice, although the effects disappeared completely from the cells prepared from $I P^{-/-}$mice. In contrast, $\mathrm{PGE}_{2}$ had no effect on renin mRNA expression in the cells prepared from WT mice. Each point represents mean \pm SEM of 4 cell groups. ${ }^{*} P<0.05$ versus WT mice.

of the responsible prostanoids remain elusive, however. Here we showed that IP deficiency significantly suppressed the development of renovascular hypertension in vivo, demonstrating for the first time that endogenous $\mathrm{PGI}_{2}$ plays an important role in the pathogenesis of renovascular hypertension by way of the IP. In contrast, the deficiency of $E P_{1}^{-/-}, E P_{2}^{-/-}, E P_{3}^{-/-}$, or $E P_{4}^{-/-}$did not attenuate at all the development of renovascular hypertension in the $2 \mathrm{~K} 1 \mathrm{C}$ model. This suggests that endogenous $\mathrm{PGE}_{2}$ does not participate in the pathogenesis of renovascular hypertension, at least in the present model of renovascular hypertension. There may be, however, some fixation of particular genes in $\mathrm{EP}_{4}^{-/-}$mice due to a selective bleeding as described. Therefore, it would be necessary to give care to the difference in genetic background when considering in vivo phenotype of $\mathrm{EP}_{4}^{-/-}$mice, because the factors responsible for $\mathrm{BP}$ response would be different according to a genetic background.

The pivotal role of the RAA system in the development of renovascular hypertension is well-established. In $I P^{-/-}$mice, the increases in PRA and PAC were significantly lower compared with those in WT mice, indicating the stimulatory actions of endogenous $\mathrm{PGI}_{2}$ on renin and succeeding aldosterone secretions. In addition, the expression level of renin mRNA was significantly elevated in the WT kidney after the operation, although the elevation was significantly blunted in $I P^{-/-}$kidney, indicating that endogenous $\mathrm{PGI}_{2}$ also stimulates renin production. These results suggest that the role of $\mathrm{PGI}_{2}$ in the development of renovascular hypertension was mediated by activation of the RAA system.

Immunohistochemical analysis detected the renin immunoreactivities only in JG cells in the kidney from shamoperated mice. In the kidney of $2 \mathrm{~K} 1 \mathrm{C}$, however, the renin immunoreactivities were additionally found in the afferent arterioles adjacent to the glomeruli. This expansion of renin immunoreactivities toward afferent arterioles corresponds to the fact that intermediated cells in the media of the afferent arteriole can produce renin granules upon a decrease in perfusion pressure of the kidney (6). We previously showed that the IP was expressed in smooth muscle cells of the afferent arterioles in the murine kidney (11). Taken together, these findings suggest that $\mathrm{PGI}_{2}$ produced in the arterioles could act at the IP on intermediate cells transformed to contain renin granules as well as at the IP on JG cells.

We determined which isoform of COXs is responsible for production of $\mathrm{PGI}_{2}$ participating in the pathogenesis of renovascular hypertension. Expression of COX-2 mRNA, but not COX-1 mRNA, increased significantly after the operation in both WT and $I P^{-/-}$kidneys to a similar degree. In addition, PRA and the expression level of renal renin mRNA in SC-58125treated WT mice were significantly lower than those in vehicletreated WT mice and were similar to those in vehicle-treated $I P^{-/-}$mice. Moreover, SC-58125 failed to affect these parameters in $I P^{-/-}$mice. These results suggest that COX-2-derived $\mathrm{PGI}_{2}$ is responsible for the activation of the RAA system in renovascular hypertension. Nevertheless, SC-58125 failed to significantly suppress sBP. Several investigators have reported the effects of COX inhibitors in renovascular hypertension, although the results are controversial. Some reports suggested significant suppressive effects of COX-2 inhibitors on BP in renovascular hypertension $(12,13)$. In contrast, the absence of effects of these inhibitors on $\mathrm{BP}$ and renin production in the $2 \mathrm{~K} 1 \mathrm{C}$ model have been shown $(14,15)$. This discrepancy may be derived from the effects of COX-2 inhibitors on a variety of systemic actions of the prostanoids in the body irrespective of their potent inhibitory effect on renin secretion and production, as shown in this
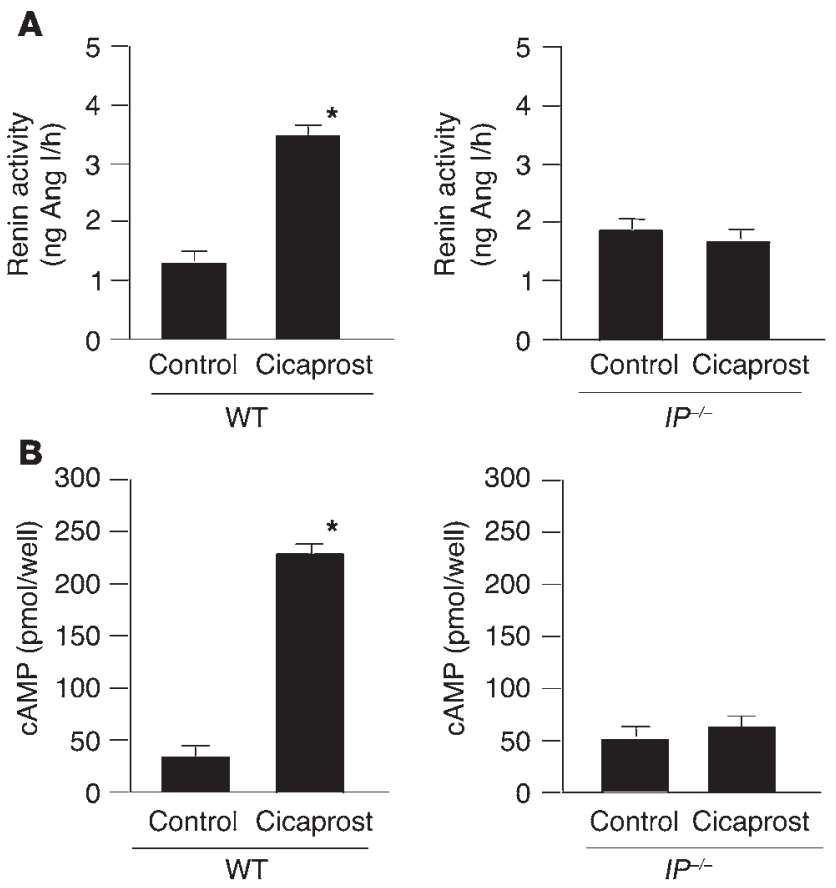

\section{Figure 6}

Effects of cicaprost on renin activity and cAMP contents in cultured cells rich in JG cells. Cicaprost $(1 \mu \mathrm{M})$ significantly increased the renin activity (A) and cAMP contents (B) in the cells prepared from WT mice, while the effects disappeared completely in the cells prepared from $I P^{-/-}$mice. Each point represents mean \pm SEM of 4 cell groups. ${ }^{\star} P<0.05$ versus control. 
study. Otherwise, the failure of SC-58125 to suppress BP elevation in the present study may originate from its relatively moderate effect on $\mathrm{PGI}_{2}$ production due to a mild dose protocol.

We examined whether $\mathrm{PGI}_{2}$ also plays a role in the regulation of the RAA system through the macula densa mechanism under saltdeficient conditions. In WT mice, a low-salt diet with furosemide significantly increased PRA and renin mRNA expression, indicating an activation of the RAA system. In $\mathrm{IP}^{-/-}$mice, however, these increases were significantly blunted, indicating that endogenous $\mathrm{PGI}_{2}$ also participates in macula densa mechanism of renin release and production. In addition, SC-58125 significantly reduced salt deficiency-induced increases in PRA and renin mRNA expression in WT mice to a level similar to those in vehicle-treated $I P^{-/-}$mice. These inhibitory effects of SC-58125 on the RAA system, however, disappeared in $\mathrm{IP}^{-/-}$mice, suggesting that $\mathrm{COX}-2$-derived $\mathrm{PGI}_{2}$ participates in the macula densa mechanism.

In both the $2 \mathrm{~K} 1 \mathrm{C}$ and salt restriction model, the activation of the RAA system in $I^{-/-}$mice was significantly blunted compared with that in WT mice. The activity of the RAA system was still significantly higher in $I P^{-/-}$mice compared with that in control mice, however. This result suggests that the IP-independent mechanism through factors other than $\mathrm{PGI}_{2}$, such as sympathetic nervous system and nitric oxide, would be involved in the activation of the RAA system in the pathogenesis of renovascular hypertension and under the condition of salt deficiency. In addition, possible contribution of other prostanoids in the regulation of the RAA system, such as $\mathrm{PGD}_{2}$, $\mathrm{PGF}_{2} \mathrm{\alpha}$, and $\mathrm{TXA}_{2}$, could not be excluded in the present study.

Finally, we examined whether $\mathrm{PGI}_{2}$ acts directly at JG cells. In the cultured cells from WT mice, cicaprost exhibited a potent stimulatory effect on renin mRNA expression and renin activity, effects that disappeared completely in cultured cells from $I P^{-/-}$mice. In contrast, $\mathrm{PGE}_{2}$ and selective $\mathrm{EP}$ agonists had no effect on renin mRNA expression and renin activity in the cultured cells from WT mice. In addition, cicaprost potently increased cAMP contents in the cultured cells in an IP-dependent manner. In accordance with this result, a stimulatory effect of $\mathrm{PGI}_{2}$ on renin production and cAMP contents in cultured JG cells has been reported (10). These results indicate that $\mathrm{PGI}_{2}$ is a potent stimulant of renin mRNA expression acting directly on JG cells and that the effect of $\mathrm{PGI}_{2}$ is mediated by increased cAMP contents. In contrast to the present result, however, several reports have suggested a stimulatory effect of $\mathrm{PGE}_{2}$ on renin mRNA expression in cultured JG cells $(10,16)$. Although the reason for this discrepancy is not clear, it may be derived from a species difference. In fact, a reported $\mathrm{EC}_{50}$ value of $\mathrm{PGE}_{2}$ in renin mRNA expression in cultured murine JG cells is more than two rank orders higher compared with that of $\mathrm{PGI}_{2}(10)$, indicating a low potency of $\mathrm{PGE}_{2}$ in mouse JG cells. Otherwise, this discrepancy may be attributed to a difference in the experimental condition.

In conclusion, $\mathrm{COX}$-2-derived $\mathrm{PGI}_{2}$ plays a critical role through the IP in regulating the release of renin and consequently renovascular hypertension in vivo. The mediatory role of $\mathrm{PGI}_{2}$ also occurred in the macula densa mechanism of renin secretion, indicating that $\mathrm{PGI}_{2}$ is a key molecule in the regulation of renin release.

\section{Methods}

Mice. Generation and maintenance of $\mathrm{EP}^{-/-}, \mathrm{EP}_{2}^{-/-}, \mathrm{EP}_{3}^{-/-}, \mathrm{EP}_{4}^{-/-}$, and $\mathrm{IP}^{-/-}$ mice have been reported (17-20). The $\mathrm{EP}_{1^{-/-}}, \mathrm{EP}_{2}^{-/-}, \mathrm{EP}_{3}^{-/-}$, and WT control mice have a genetic background similar to $\mathrm{C} 57 \mathrm{BL} / 6$ mice. Most $\mathrm{EP}_{4}^{-/-}$mice die postnatally as a result of patent ductus arteriosus and do not survive at all in the C57BL/6 background. Therefore, F2 progenies of surviving $\mathrm{EP}_{4}^{-/-}$mice and their WT littermates were maintained independently in the mixed genetic background of 129/Ola and C57BL/6. For the experiments using $\mathrm{EP}_{4^{-/-}}$mice, F2-WT mice having this genetic background were used as a control. All experiments, which were approved by the Asahikawa Medical College Committee on Animal Research, were performed using 10- to 20-week-old female mice.

The $2 \mathrm{~K} 1 \mathrm{C}$ procedure as a model of renovascular bypertension. The $2 \mathrm{~K} 1 \mathrm{C}$ procedure was performed according to the reported method (21) with some modification. Mice were anesthetized with ketamine $(100 \mathrm{mg} / \mathrm{kg}$, intraperitoneally) and xylazine ( $5 \mathrm{mg} / \mathrm{kg}$, intraperitoneally), and were placed in a prone position under a control of body temperature. The left kidney was exposed through the posteroabdominal incision, and the renal artery was individualized from the renal vein and nerves over a short segment, along which a fluorocarbon thread (Siglon; Sunline Co. Ltd.) $5 \mathrm{~mm}$ long, with a diameter of $0.11 \mathrm{~mm}$, was placed. A clip was then made by twisting $10 \mathrm{~mm}$ of copper wire around the renal artery and the thread, which was removed after the clipping. In a pilot experiment, the diameter of the stenosis was estimated by measuring the diameter of the clips, which were removed from mice 24 hours after the operation. Digitalized photographs of the clips captured by CCD camera were analyzed by the software program NIH image, and the diameter of the clips thus measured was $0.11 \pm 0.01 \mathrm{~mm}(n=9)$. Renal blood flow estimated by laser-Doppler method (ALF21; Advantec MFS Inc.) fell to a level of about $30 \% \pm 1.6 \%$ of the preclipping value $(n=5)$. The procedure gave a fairly constant degree of elevation in BP, and $91 \%$ of WT mice subjected to $2 \mathrm{~K} 1 \mathrm{C}(n=109)$ showed the increase in sBP greater than $50 \%$ of the mean increase of all WT mice. A sham procedure, which included the entire surgery with the exception of arterial clipping, was applied in control mice.

To examine the effect of SC-58125 (Cayman Chemical Co.), a selective COX-2 inhibitor $(22,23)$, in the $2 \mathrm{~K} 1 \mathrm{C}$ model we administered it at days 5 and 6 of 2K1C. SC-58125 dissolved in DMSO at a concentration of $20 \mathrm{mg} /$ $\mathrm{ml}$ was injected intraperitoneally at a dose of $0.5 \mu \mathrm{l} / \mathrm{g}$ body weight $(10 \mathrm{mg} /$ $\mathrm{kg}$ body weight) using a microsyringe (no. 710; Hamilton Co.). The dose of DMSO had no effect on BP, PRA, and renin mRNA expression. We chose a dose protocol of SC-58125, $10 \mathrm{mg} / \mathrm{kg}$ for 2 days, because SC-58125 administrated at $20 \mathrm{mg} / \mathrm{kg}$ for 2 days had an inhibitory effect on COX-1, which was estimated by the reduction of plasma level of $\mathrm{TXB}_{2}(22)$, a COX-1-related metabolite. In addition, we found a sign of gastric damage by high doses of SC-58125, which was represented by reduction of gastric weight (23).

The incidence of minute renal infarction after the operation was estimated by examining the degree of sclerotic change in glomeruli at day 7 of $2 \mathrm{~K} 1 \mathrm{C}$ because no gross infarction was detected histologically. There was no significant difference in the percentage of sclerotic or collapsed glomeruli between WT and $I P^{-/-}$kidneys; these were $4.7 \% \pm 1.8 \%(n=10)$ and $5.0 \% \pm 3.2 \%(n=12)$, respectively. This result indicates that the tendency to thrombosis found in $I P^{-1-}$ mice was not apparent in the present $2 \mathrm{~K} 1 \mathrm{C}$ model.

$\mathrm{BP}$ was measured by a method using tail plethysmography (Softron Co. Ltd.) as reported (24). We also measured BP directly from the carotid artery in some experiments in which the left carotid artery was cannulated with a polyurethane catheter (Instech Laboratories Inc.) at day 7 of $2 \mathrm{~K} 1 \mathrm{C}$, and the BP was measured with a polygraph (San-Ei Instrument Co. Ltd.) after recovery from anesthesia.

Low-salt diet with furosemide. Mice were fed with a normal diet containing $0.33 \% \mathrm{NaCl}$ or a low-salt diet containing $0.12 \% \mathrm{NaCl}$ (Oriental Yeast Co. Ltd.) for 7 days. Mice on a low-salt diet also received an intraperitoneal injection of furosemide $(25 \mathrm{mg} / \mathrm{kg})$ everyday. At days 5 and 6 of salt depletion, $10 \mathrm{mg} / \mathrm{kg}$ of SC-58125 was injected intraperitoneally.

Measurements of PRA and PAC. PRA was measured according to the reported method (25) with some modifications. In short, blood (400 $\mu \mathrm{l})$ was collected from the heart, and $8 \mu \mathrm{l}$ of $0.5 \mathrm{M}$ EDTA ( $\mathrm{pH}$ 8.0) was added. After centrifugation at $1,500 \mathrm{~g}$ for 10 minutes, plasma was collected and stored at $-80^{\circ} \mathrm{C}$ until use. To determine PRA, plasma $(10 \mu \mathrm{l})$ was incubated for 1 
hour at $37^{\circ} \mathrm{C}$ with $10 \mu \mathrm{l}$ of plasma prepared from nephrectomized mice 36 hours after the operation plus $10 \mu \mathrm{l}$ of phosphate buffer $(50 \mathrm{mM}, \mathrm{pH}$ 6.6). The generated Ang I was measured by an enzyme immunoassay (EIA) kit (Peninsula Laboratory Inc.). Residual renin activity in plasma from nephrectomized mice was subtracted from the PRA of each sample. The PAC was measured by an EIA kit (Cayman Chemical Co.).

Examination of renin and COX $m R N A$ expressions in the kidney. After the kidney was excised, the renal cortex was separated from the medulla along the inner stripe of outer medulla, frozen in liquid nitrogen, and stored at $-80^{\circ} \mathrm{C}$ until use. Total RNA $(2 \mu \mathrm{g})$, which was isolated from the renal cortex using Isogen (Nippon Gene Co. Ltd.), was reverse-transcribed as reported (26). The resulting cDNA was amplified by PCR using primer sets corresponding to the respective mRNA for renin, COX-1, COX-2, and $\beta$ - actin $(27,28)$. The quantity of PCR product was determined by real-time PCR analysis using a Lightcycler apparatus (Idaho Technology Inc.) and DNA Master SYBR Green I (Roche Molecular Biochemicals).

Immunohistochemical analysis of renin expression in the WT kidney. After fixation by perfusion and immersion with $4 \%$ paraformaldehyde, the kidney was embedded in paraffin. Tissue sections ( $5 \mu \mathrm{m}$ thick) prepared from paraffin-embedded kidneys were washed in a buffer containing $0.05 \%$ polyoxyethylene sorbitan monolaurate (Tween 20; ICN Biomedicals Inc.) and incubated with normal rabbit serum for 10 minutes at room temperature. These tissue sections were then incubated with the first $\mathrm{Ab}$ for renin (Swant) for 20 minutes at room temperature. After the sections were incubated with secondary $\mathrm{Ab}$ (Histofine; Nichirei Corp.) for 20 minutes at room temperature, the immunocomplexes were visualized using the strepto-avidin-biotin complex method (Nichirei Corp.). Each section was counterstained with hematoxylin (Wako Pure Chemical Industries Ltd.). As a negative control, we used preimmune mouse IgG (DAKO Corp.).

Measurements of 6-keto-PGF $F_{1} \alpha$ and creatinine contents in plasma and urine. Plasma and urinary contents of 6-keto-PGF ${ }_{1} \alpha$, a stable metabolite of $\mathrm{PGI}_{2}$, were measured by an EIA kit (Cayman Chemical Co.). Contents of creatinine in plasma and urine were measured by the method of FolinWu (described in ref. 29).

Isolation and culture of JG cells. JG cells were separated and cultured according to the reported method (30). The kidneys were removed, decapsulated, and minced with a surgical blade. After the minced tissue was incubated with $0.1 \%$ collagenase for 15 minutes at $37^{\circ} \mathrm{C}$, it was filtered through a 40- $\mu \mathrm{m}$ nylon mesh. The filtered cells were put on $15 \mathrm{ml}$ of $30 \%$ isosmotic Percoll solution (Amersham Biosciences) and centrifuged at 27,000 $\mathrm{g}$ for 20 minutes at $4^{\circ} \mathrm{C}$. The cell layer enriched with JG cells near the surface was collected and washed (31). The cells $\left(10^{5}\right)$ were then plated onto a collagen-coated dish $(60 \mathrm{~mm})$ in $5 \mathrm{ml}$ of culture medium: RPMI-1640 supplemented with $2 \% \mathrm{FBS}$, transferrin $(10 \mu \mathrm{g} / \mathrm{ml})$, insulin $(10 \mu \mathrm{g} / \mathrm{ml})$, sodium selenite $(0.67 \mathrm{ng} / \mathrm{ml})$, penicillin $(50 \mathrm{U} / \mathrm{ml})$, and streptomycin $(50 \mu \mathrm{g} / \mathrm{ml})$ (Invitrogen Corp.). The cells were cultured for 20 hours in a humidified atmosphere containing $5 \% \mathrm{CO}_{2}$ at $37^{\circ} \mathrm{C}$. After the culture medium was changed to a fresh one containing indomethacin $(10 \mu \mathrm{M})$, various con-

1. Pickering, T.G., and Laragh, J.H. 1991. Renovascular hypertension. In The kidney. B.M. Brenner and F.C. Rector, Jr., editors. W.B. Saunders Co. Philadelphia, Pennsylvania, USA. 1940-1967.

2. Hartner, A., Goppelt-Struebe, M., and Hilgers, K.F. 1998. Coordinate expression of cyclooxygenase-2 and renin in the rat kidney in renovascular hypertension. Hypertension. 31:201-205.

3. Harris, R.C., and Breyer, M.D. 2001. Physiological regulation of cyclooxygenase- 2 in the kidney. Am. J. Physiol. 281:F1-F11.

4. Imanishi, M., Tsuji, T., Nakamura, S., and Takamiya, M. 2001. Prostaglandin $\mathrm{I}_{2} / \mathrm{E}_{2}$ ratios in unilateral renovascular hypertension of different severities. Hypertension. 38:23-29.

centrations of cicaprost (Schering AG), an IP agonist, or $\mathrm{PGE}_{2}$ (Cayman Chemical Co.) were added, and the cells were incubated further for 20 hours. In some experiments, the cells were incubated with $1 \mu \mathrm{M}$ of DI-004, AE1-259, AE-248, and AE1-329 (Ono Pharmaceutical Co.); these are the selective agonists for $\mathrm{EP}_{1}, \mathrm{EP}_{2}, \mathrm{EP}_{3}$, and $\mathrm{EP}_{4}$, respectively $(32,33)$. After the cell culture, total RNA was prepared, and RT-PCR analyses for renin mRNA expression were performed. For the examination of renin activity, the cells were disrupted by sonication and were centrifuged at 2,000 $\mathrm{g}$ for 5 minutes. Then the supernatant was used for the measurement of renin activity.

The JG cells were identified as the positive cells for renin immunoreactivity. We applied the prepared cells onto a glass slide optimized for tissue culture (Falcon; $\mathrm{BD}$ ) and incubated them with an $\mathrm{Ab}$ for renin (Swant). After staining of the cells with hematoxylin, we counted a number of cells positive for renin immunoreactivity and determined the purity of the cells. The average content of the renin-positive cells was $26 \%$ of the total cells. The other $74 \%$ cells were mainly spindle-shaped and might represent fibroblastic or mesangial cells (31), although we could not identify the types of these cells.

Measurements of cAMP contents in the cultured cells. The isolated cells rich in JG cells $\left(2 \times 10^{4}\right)$ were plated onto a 24-well culture plate in $0.5 \mathrm{ml}$ of the culture medium. After 24 hours of culture, the cells were washed twice with a serum-free medium, and $0.5 \mathrm{ml}$ of RPMI- 1640 containing $1 \mathrm{mM}$ 3 -isobutyl-1-methylxanthine and $0.1 \% \mathrm{BSA}$ was added. After preincubation for 10 minutes at $37^{\circ} \mathrm{C}$, the cells were stimulated with $1 \mu \mathrm{M}$ of cicaprost for 30 minutes. The incubations were terminated by adding $0.5 \mathrm{ml}$ of $6 \%$ perchloric acid, and the cAMP contents were measured as reported (26).

Data analysis. All data were expressed as mean plus or minus SEM. Statistical comparison of data were made with repeated two-way ANOVA followed by a Bonferroni/Dunn test for multiple comparison. Differences were considered significant if $P$ values were less than 0.05 .

\section{Acknowledgments}

We thank K. Nakaya and T. Yokoyama for help in breeding and maintenance of mice, K. Nakanishi for experimental assistance, and Y. Takashima for secretarial assistance. This work was supported by Grants-in-Aid for Scientific Research from the Ministry of Education, Science, Sports and Culture of Japan and by the Research Grant for Cardiovascular Disease (14A-1) from the Ministry of Health and Welfare. This work was also supported by grants from Ono Pharmaceutical Co., the Smoking Research Foundation, and Hokkaido Heart Association.

Received for publication February 20, 2004, and accepted in revised form July 14, 2004.

Address correspondence to: Fumitaka Ushikubi, Department of Pharmacology, Asahikawa Medical College, Midorigaoka Higashi 2-1-1-1, Asahikawa 078-8510, Japan. Phone: 81-166-68-2362; Fax: 81-166-68-2369; E-mail: ushikubi@asahikawa-med.ac.jp.

5. Jackson, E.K., Gerkens, J.F., Brash, A.R., and Branch, R.A. 1982. Acute renal artery constriction increases renal prostaglandin $\mathrm{I}_{2}$ biosynthesis and renin release in the conscious dog. J. Pharmacol. Exp. Ther. 222:410-413.

6. Hackenthal, E., Paul, M., Ganten, D., and Taugner, R 1990. Morphology, physiology, and molecular biology of renin secretion. Physiol. Rev. 70:1067-1116.

7. Kurtz, A., and Wagner, C. 1999. Cellular control of renin secretion. J. Exp. Biol. 202:219-225.

8. Ushikubi, F., Hirata, M., and Narumiya, S. 1995. Molecular biology of prostanoid receptors; an overview. J. Lipid Mediat. Cell Signal. 12:343-359.

9. Narumiya, S., Sugimoto, Y., and Ushikubi, F. 1999. Prostanoid receptors: structures, properties, and functions. Physiol. Rev. 79:1193-1226.

10. Jensen, B.L., Schmid, C., and Kurtz, A. 1996. Prostaglandins stimulate renin secretion and renin mRNA in mouse renal juxtaglomerular cells. Am. J. Physiol. 271:F659-F669.

11. Oida, H., et al. 1995. In situ hybridization studies of prostacyclin receptor mRNA expression in various mouse organs. Br. J. Pharmacol. 116:2828-2837.

12. Imanishi, M., et al. 1989. Aspirin lowers BP in patients with renovascular hypertension. Hypertension. 14:461-468.

13. Wang, J.L., Cheng, H.F., and Harris, R.C. 1999. Cyclooxygenase- 2 inhibition decreases renin content and lowers BP in a model of renovascular hypertension. Hypertension. 34:96-101. 
14. Hartner, A., Cordasic, N., Goppelt-Struebe, M., Veelken, R., and Hilgers, K.F. 2003. Role of macula densa cyclooxygenase- 2 in renovascular hypertension. Am. J. Physiol. 284:F498-F502.

15. Mann, B., et al. 2001. Acute upregulation of COX-2 by renal artery stenosis. Am. J. Physiol. 280:F119-F125.

16. Yang, T., et al. 2000. Low chloride stimulation of prostaglandin $\mathrm{E}_{2}$ release and cyclooxygenase- 2 expression in a mouse macula densa cell line. J. Biol. Chem. 275:37922-37929.

17. Murata, T., et al. 1997. Altered pain perception and inflammatory response in mice lacking prostacyclin receptor. Nature. 388:678-682.

18. Hizaki, H., et al. 1999. Abortive expansion of the cumulus and impaired fertility in mice lacking the prostaglandin E receptor subtype $\mathrm{EP}_{2}$. Proc. Natl. Acad. Sci. U. S. A. 96:10501-10506.

19. Segi, E., et al. 1998. Patent ductus arteriosus and neonatal death in prostaglandin receptor EP4deficient mice. Biochem. Biophys. Res. Commun. 246:7-12.

20. Ushikubi, F., et al. 1998. Impaired febrile response in mice lacking the prostaglandin $\mathrm{E}$ receptor subtype $\mathrm{EP}_{3}$. Nature. 395:281-284.

21. Wiesel, P., Mazzolai, L., Nussberger, J., and
Pedrazzini, T. 1997. Two-kidney, one clip and onekidney, one clip hypertension in mice. Hypertension. 29:1025-1030.

22. Sheng, H., et al. 1997. Inhibition of human colon cancer cell growth by selective inhibition of cyclooxygenase-2. J. Clin. Invest. 99:2254-2259.

23. Seibert, K., et al. 1994. Pharmacological and biochemical demonstration of the role of cyclooxygenase 2 in inflammation and pain. Proc. Natl. Acad. Sci. U. S. A. 91:12013-12017.

24. Johns, C., Gavras, I., Handy, D.E., Salomao, A., and Gavras, H. 1996. Models of experimental hypertension in mice. Hypertension. 28:1064-1069.

25. Menard, J., and Catt, K.J. 1972. Measurement of renin activity, concentration and substrate in rat plasma by radioimmunoassay of angiotensin I. Endocrinology. 90:422-430.

26. Fujino, T., et al. 2002. Effects of the prostanoids on the proliferation or hypertrophy of cultured murine aortic smooth muscle cells. Br.J. Pharmacol. 136:530-539.

27. Bruna, R.D., Kurtz, A., Corvol, P., and Pinet, F. 1993. Renin mRNA quantification using polymerase chain reaction in cultured juxtaglomerular cells. Short-term effects of cAMP on renin mRNA and secretion. Circ. Res. 73:639-648.

28. Yang, T., et al. 2000. Renin expression in COX-2$\mathrm{KO}$ mice on normal or low-salt diets. Am. J. Physiol. 279:F819-F825.

29. Bonsnes, R.W., and Taussky, H.H. 1945. On the colorimetric determination of creatinine by the Jaffe reaction. J. Biol. Chem. 158:581-591.

30. Gambaryan, S., et al. 1998. Endogenous or overexpressed cGMP-dependent protein kinases inhibit cAMP-dependent renin release from rat isolated perfused kidney, microdissected glomeruli, and isolated juxtaglomerular cells. Proc. Natl. Acad. Sci.U.S. A. 95:9003-9008.

31. Della Bruna, R., Pinet, F., Corvol, P., and Kurtz, A. 1991. Regulation of renin synthesis by second messengers in isolated mouse juxtaglomerular cells. Cell Physiol. Biochem. 1:98-110.

32. Kabashima, K., et al. 2002. The prostaglandin receptor EP4 suppresses colitis, mucosal damage and CD4 cell activation in the gut. J. Clin. Invest. 109:883-893. doi:10.1172/JCI200214459.

33. Suzawa, T., et al. 2000. The role of prostaglandin $\mathrm{E}$ receptor subtypes (EP1, EP2, EP3, and EP4) in bone resorption: an analysis using specific agonists for the respective EPs. Endocrinology. 141:1554-1559. 